\title{
Distribution of Royle's Pika Ochotona roylei in Parvati Kunda Groundwater Complex
}

\author{
Mohan Bikram Shrestha*, and Ritu Gurung
}

Wildlife Conservation Nepal, Kathmandu, Nepal

\begin{abstract}
Royle's Pika Ochotona roylei is high altitude animal belonging to the family Ochotonidae in order Lagomorpha. Royle's Pika was reported in different locations between an elevation of 2180 to 5950 meters above sea level ( $\mathrm{m}$ asl). This study carried in February and October 2017 recorded a small population of Royle's Pika in the Parvati Kunda Groundwater Complex of Gatlang village in Rasuwa District, Nepal. A total of 12 Royle's pika individuals were head counted from three sites while Pika foraged plants were observed in other sites. Pika was observed in talus groove amidst Rhododendron-fir forest, Fir-hemlock forest, and Rhododendron shrub close to the alpine meadow. Pika in the study was distributed from the Parvati Kunda wetland proximity at an elevation of $2605 \mathrm{~m}$ with a direct count of 2 individuals to an elevation of $3000 \mathrm{~m}$ asl beneath Tshumer hill with a headcount of 7 individuals. However, the population of Royle's Pika in the area was estimated more. The population density of 6 individuals/hectare was calculated in the area, which is relatively lower than the population density accounted for in other areas.
\end{abstract}

Keywords: Distribution, Gatlang, Parvati Kunda, Royle's Pika

\section{Introduction}

Pikas are high altitude animals. Taxonomically, Pikas belongs to the family Ochotonidae in order Lagomorpha (Hares, Rabbits and Pikas). These are diurnal animals and easily visible, making them ideal for field observation (Beever et al., 2010). They are territorial and do not hibernate (Bahuguna \& Upadhyay, 2009). Among 28 recognized pika species distributed in the world (Lissovsky, 2014), five species of pikas; Black-lipped Pika Ochotona curzoniae, Nubra Pika O. nubrica, Moupin Pika O. thibetana, Large-eared Pika O. macrotis, and Royles's Pika O. roylei reported from Nepal (Thapa et al., 2011; Thapa et al., 2018). Royle's Pika is common throughout the Himalayan region (Hoffmann \& Smith, 2005). In Nepal, this species has been reported for its occurrence in several locations such as the upper course of Daraudai Khola, Gorkha at an elevation of 3300 meters above sea level ( $\mathrm{m}$ asl) (Kawamichi, 1968), Makalu Base Camp at an elevation of $4900 \mathrm{~m}$ (Gregori \& Petrov, 1976); Phematan, Yanle Kharka, front of Barun Glacier (4900 m asl), the base of the southwestern face of Mt. Makalu (5950 $\mathrm{m}$ asl) (Daniel \& Hanzák, 1985). In Api Nampa Conservation Area, Royle's Pika was observed from an elevation of $3098 \mathrm{~m}$ asl through the indirect sign, active burrows from $3263 \mathrm{~m}$ asl and direct observation from 3738 $\mathrm{m}$ asl, (Koju et al., 2013). Royle's Pika in Langtang National Park have been recorded from Gosainkunda village (4300 m asl), between Dhunche and Goasainkunda village (3500 m asl), Tharepati (3300 $\mathrm{m}$ asl) of the south ridge of Thare Pati (Abe, 1971), Goasainkunda pass at an elevation of $4750 \mathrm{~m}$ asl (Agrawal \& Chakraborty, 1971; Mitchell, 1978), Dhukpu (3864 $\mathrm{m}$ asl), Tharepati (3385 $\mathrm{m}$ asl), Phulung Ghyang (2550 $\mathrm{m}$ asl, should be $3550 \mathrm{~m}$ asl), Namsangsang (4360 $\mathrm{m}$ asl), Langtang valley at an elevation of $3300 \mathrm{~m}$ asl, (Mitchell,
1978), Helambu area at an elevation approximately 4500$5000 \mathrm{~m}$ asl (Chesemore, 1970), Lama hotel area at $2800 \mathrm{~m}$ asl (Khanal \& Shrestha, 2000), near Lama hotel (2900 $\mathrm{m}$ asl) in route to Kyangin (Deo et al., 2008). Pellets of pika observation at farmland in Dimsa (3005 $\mathrm{m}$ asl) along Gosainkunda route and direct observation of Pika in Langtang route at $3018 \mathrm{~m}$ asl (Koju et al., 2014), and between 2590 - $5090 \mathrm{~m}$ asl in Langtang National Park (Green, 1981) were also recorded. In Everest region, Pikas along Dudh Koshi River below Namche Bazar (2800 m asl) to Makyong near Deboche (4150 m asl), near Thyangboche Gompa at an altitude of $3800 \mathrm{~m}$ - $4000 \mathrm{~m}$ asl, Khumjung (3673 $\mathrm{m}$ asl) Solukhumbu district and Seti Gompa (2650 m asl) in between Phaplu and Those based on fecal pellets deposition and suggested pikas do not occur at a lower elevation (Kawamichi, 1971). Royle's Pika in Annapurna region reported from Muktinath and Manangbhot at an elevation of $5300 \mathrm{~m}$ asl (Chesemore, 1970) and West side of Thorong la pass between and Muktinath (3581 $\mathrm{m}$ asl) Mustang district (Lewis, 1971) and Ulleri at an elevation of $2180 \mathrm{~m}$ asl (Abe, 1971). All these records are from protected areas. Outside the protected area, Royle's pika pellets were observed in the Roshan area, in Achham districts between 2515 and $3242 \mathrm{~m}$ asl and pika specimens in Bagkal area (3242 $\mathrm{m}$ asl) located in borderline to Achham and Kalikot district of far-west Nepal (Shrestha et al., 1999). Khanal (2007) recorded Royle's Pika from 3300 m asl near Somdang of Ganesh Himal area of Central Nepal. This study presents the distribution of Royle's Pika and its population density in the Parvati Kunda Groundwater Complex Area in Gatlang village in Rasuwa District of Central Nepal.

Corresponding author: shrmohan5@gmail.com 


\section{Materials and Methods}

Study area

The Parvati Kunda groundwater complex is in the Gatlang village of Rasuwa district in Central Nepal (Fig. 1). The study area is a 340-hectare basin where water (surface and groundwater) over the basin influx 1.87-hectare small wetland-Parvati Kunda. The study area hence is termed as the Parvati Kunda Groundwater complex. The Parvati Kunda ( $28^{\circ} 09^{\prime} 22^{\prime \prime} \mathrm{N}, 85^{\circ} 15^{\prime} 40^{\prime \prime}$ E) located at $2600 \mathrm{~m}$ asl is the lowest elevation while Tshumer hill $\left(28^{\circ} 08^{\prime} 41^{\prime \prime} \mathrm{N}\right.$, $85^{\circ} 15^{\prime} 28^{\prime \prime} \mathrm{E}$ ) with an altitude of $3147 \mathrm{~m}$ asl is the highest point of the study area. The region remains cold and snowy from December through February, and maximum temperature occurs between May and July. Seasonal climatic variations are dominated by the monsoon between June and September, while small scale climatic variation depends on altitude and aspect (Kharel, 1997). The seasonal rainfall and snowmelt over the region recharge the region's groundwater that drains as an aquifer in Parvati Kunda wetland. Parvati Kunda groundwater complex lies in the Bonjomane Community Forest, composed of the mixed fir-oakrhododendron forest, where the community members harvest fodder, firewood and timber and graze their livestock. The Parvati Kunda groundwater complex area mostly covered by tree vegetation composed of blue pine, oak, maple, fir, spruce, larch, Rhododendron and oval-leaf lyonia, with open meadow in some locations (Moravek et al., 2019). Physio-geographically, the area is rugged terrain northeast-facing slope architected by rainfall water washed grooves and gullies with accumulated weathered rock boulders where pika habitats were located. The area remains moist due to maximum vegetation canopy cover and Northeast facing slope.

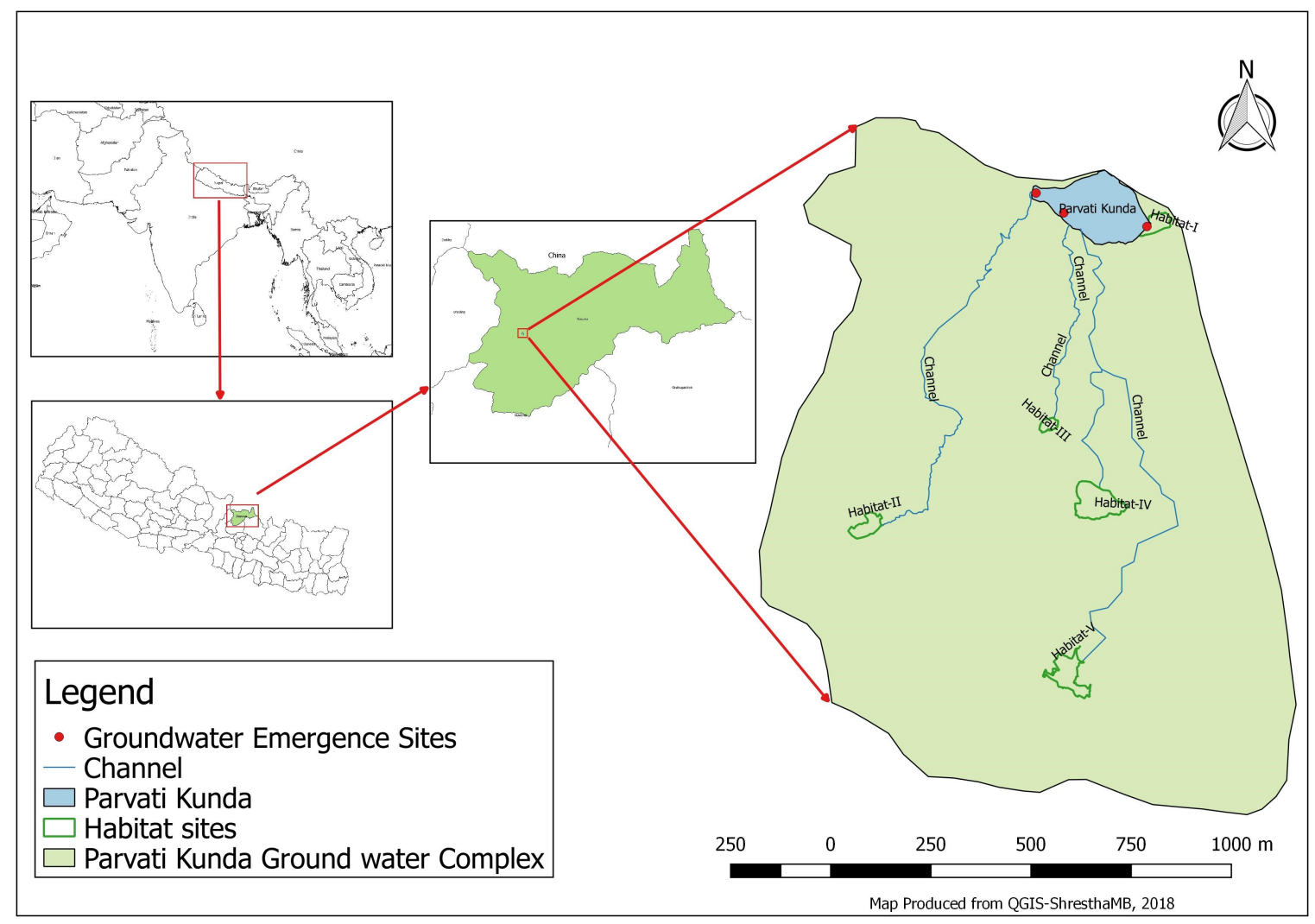

Figure 1 The study area: the Parvati Kunda Groundwater Complex

\section{Site selection and data collection}

The data for this study was collected in February and October 2017. The study site was delineated through the Google Earth, tracing the basin that influx rainfall surface or groundwater to the Parvati Kunda wetland. A total of 340 hectares were demarcated as the study area. Pika within the study area was located by the presence of pika/s, pika pellet or pika hay piles in and around the rocky debris or talus walking throughout the study area with local community members. Pikas were observed from the set vantage point in a located site covering the maximum area possible for observation in the morning (06:00-10:00) and in the evening (15:00-18:00) using binoculars (Altmann, 1974; Bahuguna et al., 2017). An observer's presence does not influence Royle's pikas' natural activity due to their synanthropic nature (Kawamichi, 1968). Pikas were directly sighted with a headcount from three sites (Site I, Site II and Site II) while Pika foraged plants were observed in rest two sites (Site IV 
and Site V) in the Parvati Kunda groundwater complex area (Fig. 1). The pika sighted area was recorded by walking around the edge of the sites recorded using the Global Positioning System (GPS) track function in Garmin GPS map 62s. Estimating pika population density in the study area was accounted for through total population count over the delineated sighted area (Koju et al., 2013).

\section{Results and Discussion}

Pika within the study area was sighted from the lowest elevation of $2605 \mathrm{~m}$ asl in Parvati Kunda wetland/Site I to the highest elevation of $3000 \mathrm{~m}$ asl beneath the Tshumer hill/Site II. The direct sighting and count of Pika were made from three sites; two individuals in the proximity of the Parvati Kunda wetland/Site-I (Fig. 2), seven individuals in the area beneath Tshumer hill/Site II, and three individuals close to Medow/Site III. Pika foraged vegetation was observed in the rest two sites (Site IV and Site V) (Fig. 3). Pika distribution in the Parvati Kunda Groundwater Complex was sighted in the area with talus groove; an oak and rhododendron forest with adjoining water body (Parvati Kunda wetland) (Site I). Also, sightings were made in talus groove in fir and hemlock forest (Site II) and Rhododendron shrubs close to the alpine meadow (site III) with seasonal brook in both later sites. Altogether 12 individuals of Royle's Pika population were headcount (Table 1). The pika population density in the Parvati Kunda groundwater complex area was accounted for 6 individuals per hectare.

Kawamichi (1971), based on the pellets, reported Royle's pika distribution from $2650 \mathrm{~m}$ asl and above in the Everest region and suggested pikas do not occur at a lower elevation. The distribution range of $O$. roylei could come down to lower elevations as low as $2400 \mathrm{~m}$ asl in Eastern Himalaya (Prater, 1971). Abe (1971) reported pika species (Ochotona sp.) from Ulleri at an elevation of $2180 \mathrm{~m}$ asl Annapurna region in Nepal, substantiating pika distribution even at a lower elevation. Shrestha et al., (1999), based on the pellet, Royle's Pika was reported from Roshan at an elevation of $2515 \mathrm{~m}$ asl in Achham district of far-western Nepal Royle's Pika. Royle's pika record in this study at an elevation of $2605 \mathrm{~m}$ asl is another lower elevation distribution record, and potentially the initial record of Royle's Pika through direct observation at such a lower elevation.

Microclimate/habitat seems a major influential factor in pika distribution, and this finding requires substantiated further. Royle's Pika was found highly distributed in a relatively humid forest zone (Kawamichi, 1971), which could be the reason for the distribution of Royle's Pika close to wetland and brooks.

Table 1 Pika sighting sites and area, pika population and pika density in the Parvati Kunda Groundwater Complex

\begin{tabular}{|c|c|c|c|c|c|c|c|}
\hline S.N. & $\begin{array}{l}\text { Observation } \\
\text { sites }\end{array}$ & Location & $\begin{array}{l}\text { Elevation range } \\
(\mathrm{m} \text { asl) }\end{array}$ & $\begin{array}{l}\text { Slope \& } \\
\text { Aspect }\end{array}$ & $\begin{array}{l}\text { Area } \\
(\mathrm{Ha})\end{array}$ & $\begin{array}{l}\text { Pika } \\
\text { Count } \\
\text { (No.) } \\
\end{array}$ & $\begin{array}{l}\text { Pika density } \\
\text { (Ind./Ha }\end{array}$ \\
\hline 1 & Site-I & $\begin{array}{l}28^{\circ} 09^{\prime} 21.4^{\prime \prime} \mathrm{N} \\
85^{\circ} 15^{\prime} 44.9^{\prime \prime} \mathrm{E}\end{array}$ & $2605-2610$ & $\begin{array}{l}11^{\circ} \\
\mathrm{S} 245^{\circ} \mathrm{W}\end{array}$ & 0.2 & 2 & \\
\hline 2 & Site-II & $\begin{array}{l}28^{\circ} 09^{\prime} 00.0 ” \mathrm{~N} \\
85^{\circ} 15^{\prime} 21.6 ” \mathrm{E}\end{array}$ & 2974-3000 & $\begin{array}{l}30-34^{\circ} \\
\mathrm{N} 33^{\circ} \mathrm{E}\end{array}$ & 0.15 & 7 & \\
\hline 3 & Site-III & $\begin{array}{l}28^{\circ} 09^{\prime} 08.0 " \mathrm{~N} \\
85^{\circ} 15^{\prime} 35.8^{\prime \prime} \mathrm{E}\end{array}$ & $2805-2828$ & $\begin{array}{l}22-24^{\circ} \\
\mathrm{N} 28^{\circ} \mathrm{E}\end{array}$ & 0.2 & 3 & $12 / 2$ \\
\hline 4 & Site-IV & $\begin{array}{l}28^{\circ} 09^{\prime} 03.2 ” \mathrm{~N} \\
85^{\circ} 15^{\prime} 40.0 ” \mathrm{E}\end{array}$ & $2840-2868$ & $\begin{array}{l}16-18^{\circ} \\
\mathrm{N} 26^{\circ} \mathrm{E}\end{array}$ & 0.87 & 0 & \\
\hline 5 & Site-V & $\begin{array}{l}28^{\circ} 08^{\prime} 50.6 ” \mathrm{~N} \\
85^{\circ} 15^{\prime} 38.7^{\prime \prime} \mathrm{E}\end{array}$ & 2978-2998 & $\begin{array}{l}25-28^{\circ} \\
\mathrm{N} 28^{\circ} \mathrm{E}\end{array}$ & 0.58 & 0 & \\
\hline \multicolumn{5}{|c|}{ Total } & 2.0 & 12 & 6 \\
\hline
\end{tabular}

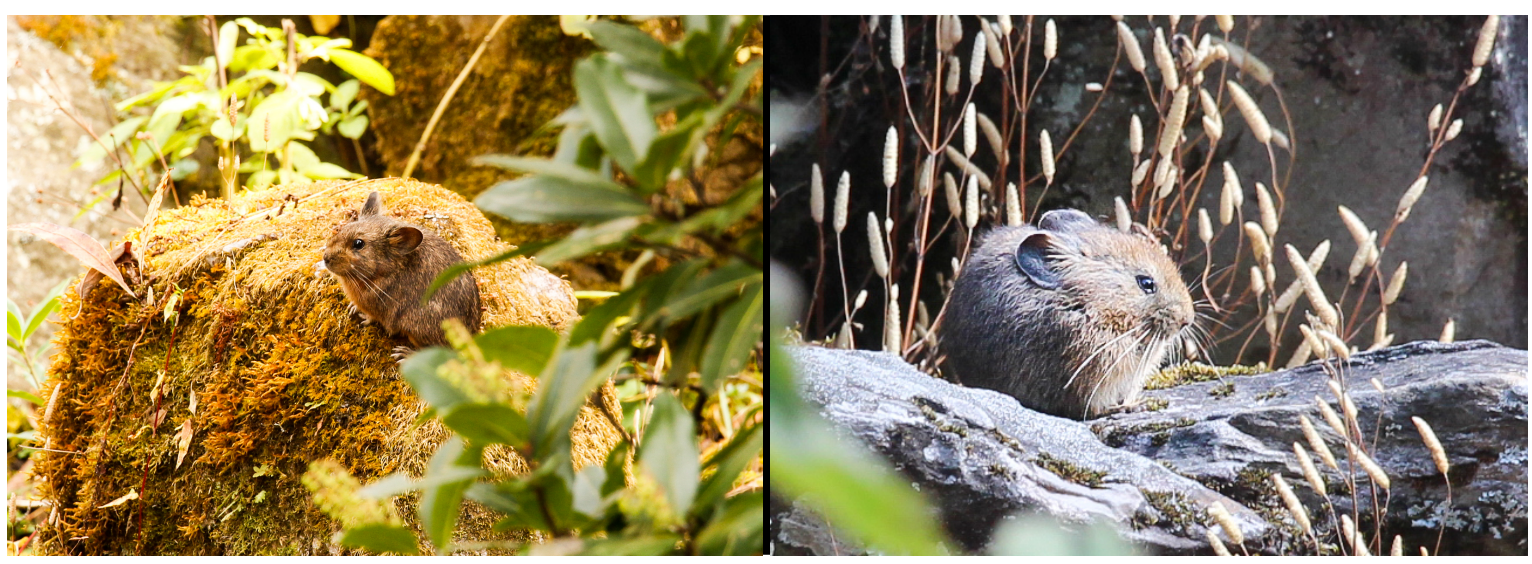

Figure 2 Royle's Pika observed in the periphery of Parvati Kunda Wetland (2605 m asl) 


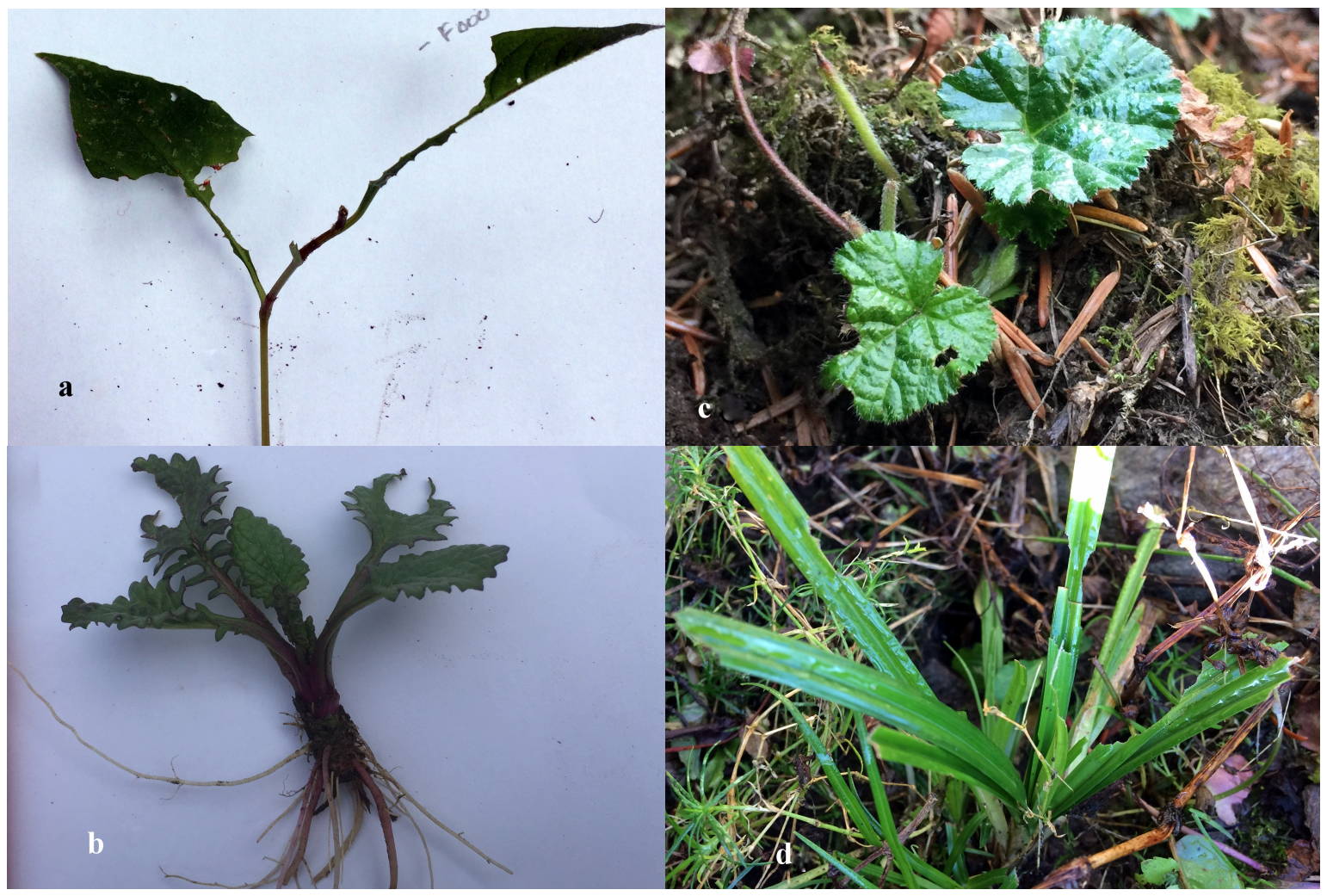

Figure 3 Pika foraged plant species (a. Persicaria sp., b. Senecio sp., c. Rubus sp., d. Aletris sp.)

Pika density in a study in the Mount Everest region was accounted for 12.5 individuals/hectare (Kawamichi, 1968) and 14 individuals/hectare in the Langtang National Park (Koju et al., 2013). Two separate studies in the different years 2012 and 2013 in the Api Nampa Conservation Area accounted for pika density of 7.2 individuals/hectare and 8 individuals/hectare (Koju \& Chalise, 2013). The pika population density in the Parvati Kunda groundwater complex area was accounted 6 individuals/hectare. The population density in the Parvati Kunda Groundwater Complex area is relatively low compared with the population density reported in other areas.

\section{Conclusion}

The distribution of Royle's Pika in the Parvati Kunda groundwater complex in the Gatlang village reported from an elevation of 2605 to $3000 \mathrm{~m}$ asl with a headcount of 12 individuals of Royle's Pika from three sites, and Pika foraged vegetation from two other sites. Pika distribution was sighted in the area with talus groove with oak and rhododendron forest in fir and hemlock and Rhododendron shrubs close to the alpine meadow perennial or seasonal water body. The pika population density in the area accounted 6 individuals/hectare.

\section{Acknowledgements}

The authors thank the Nagao Natural Environment Foundation (NEF), Japan, for financial support to carry this study. Our gratitude to Prasanna Yonzon, Wildlife Conservation Nepal (WCN) for his supervision and guidance; and Rajeshwor Rijal for his fieldwork support. Appreciation to Ban Raja Tamang, Chersingh Tamang, Mingmar Tamang, and Dorje Tamang for their fieldwork assistance and thanks to the Bonjomane Community Forest User group, Gatlang.

\section{References}

Abe, H. (1971). Small mammals of central Nepal. Journal of the Faculty of Agriculture, 56(4), 367-423.

Altmann, J. (1974). Observational study of behaviour: sampling methods. Behaviour, 49, 227-267.

Agrawal, V.C., \& Chakraborty, S. (1971). Notes on a collection of small mammals from Nepal, with a description of new Mouse-Hare (Lagomorpha; Ochotonidae), Proceedings of Zoological Society, Calcullta, 24, 41-46.

Bahuguna, S.N., \& Upadhyay, M.K. (2009). External morphology and general behaviour of Himalayan mouse hare Ochotona roylei; Lagomorpha form Garhwal 
Himalaya (Uttarakhand) India. Journal of Environment and Bio-sciences, 23(1), 9-14.

Bahuguna, S.N., Chowdhary, A.K., \& Bhardwaj, S. (2017). Habitat preference and forage selection by Himalayan Pika Ochotona roylei at high altitudinal zones of Chopta Tungnath, western Himalaya. International Journal of Zoology Studies, 2(6), 264-268.

Beever, E.A., Ray, C., Mote, P.W., \& Wilkening, J.L. (2010). Testing alternative models of climate mediated extirpations. Ecological Applications, 20(1), 164-178.

Chesemore, D.L. (1970). Notes of the mammals of the southern Nepal. Journal of Mammalogy, 51, 162-166.

Daniel, M., \& Hanzák, J. (1985). Small mammals in eastern part of Nepal Himalaya. Rozpravy Ceskoslovenské Akademie Ved, 95(8), 1-59.

Deo, R.K., Shrestha, H.K., Khanal, B., \& Devkota, S. (2008). A study on vulnerability assessment and formulation of climate change adaptation strategies for Langtang National Park and Buffer Zone. Socio-economic, Agro-Forestry and Environment (SAFE).

Green, M.J.B. (1981). A check-list and some notes concerning the mammals of the Langtang National Park, Nepal. Journal of the Bombay Natural History Society, 78(1), 77-87.

Gregori, J., \& Petrov, B. (1976). Scientific results of the Yugoslav 1972 Himalaya expedition. Mammalia. Slovenska Akademija Znanosti in Umetnosti. Classis IV: Historia Naturalis et Medicina, 19(1), 1-20.

Hoffmann, R.S., \& Smith, A.T. (2005). Oder Lagomorpha. In D.E. Wildson, \& Reeder D.M. (Eds.), Mammals species of the world, Johns Hopkins University Press Baltimore, USA, pp. 185-211.

Kawamichi, T. (1968). Winter behaviour of the Himalayan Pika Ochotona roylei. Journal of the Faculty of Science, Hokkaido University Series, Zoology, 16(4), 582-594.

Kawamichi, T. (1971). Daily activities and social pattern of two Himalayan Pikas, Ochotona macrotis and O. roylei, observed at Mt. Everest. Journal of the Faculty of Science, Hokekaido University Series, Zoology, 17(4), 587-609.

Khanal, B., \& Shrestha, K. (2000). Habitat preference by Royle's Pika (Ochotona roylei) in Gosainkunda, Rasuwa district of central Nepal. Journal of Natural History Museum, 19, 27-33.

Khanal, B. (2007). New report on the symbiotic relation of Ochotona roylei (Lagomorpha: Ochotonidae) and Scaly
Breasted Wren Babbler (Pnoepyge albiventer) at Ganesh Himalaya Area of Central Nepal. Our Nature, 5, 37-40.

Kharel, F.R. (1997). Agricultural crop and livestock depredation by wildlife in Langtang National Park, Nepal. Mountain Research and Development, 17(2), 127-134.

Koju, N.P., Chalise, M.K., \& Kyes, R.C. (2013). Ecology of Pika (Ochotona spp.) in Gosainkunda area, Langtang National Park, Nepal. In Khanna, D.R., Solanki, G.S., \& Pathak, S.K. (Eds.), Environment, biodiversity and traditional system. Biotech Books, India, pp. 75-86.

Koju, N.P., \& Chalise, M.K. (2013). Observation of Royle's Pika (Ochotona Royleı) in Api Nampa Conservation Area. Far Western Region, Nepal. Journal of Natural History Museum, 27, 78-86.

Koju, N.P., Chalise, M.K., \& Xuelong, X. (2014). Population abundance of Royle's Pikas (Ochotona roylei) along altitudinal gradients in Langtang National Park, Nepal, South Asian Journal of Multidisciplinary Studies, 2(1), 1-6.

Lewis, R.E. (1971). A new species of Chaetopsylla Kohaut, 1903, infesting pikas in Nepal (Siphonaptera: Vermipsyllidae). The Journal of Parasitology, 57(6), 13441348.

Lissovsky, A.A. (2014). Taxonomic revision of pikas Ochotona (Lagomorpha, Mammalia) at the species level. Mammalia, 78(2), 199-216.

Mitchell, R.M. (1978). The Ochotona (Lagomorpha: Ochotonidae) of Nepal, Säugetierkundliche Mitteilungen, 26(3), 208-214.

Moravek, J.A., Shrestha, M.B., \& Yonzon, S. (2019). Baseline biodiversity and physiochemical survey in Parvati Kunda and surrounding area in Rasuwa, Nepal. Journal of Threatened Taxa. 11(6), 13734-13747.

Prater, S.H. (1971). The book of Indian animals. Bombay Natural History Society, Oxford University Press.

Shrestha, K., Khanal, B., \& Karki, J.B. (1999). Foraging and haying plants of Royle's Pika (Ochotona roylei: Lagomorpha) in farwest Nepal. Journal of Natural History Museum, 18, 3-13.

Thapa, A., Dahal, B.V., Koju, N.P., \& Thapa, S. (2011). A review on pikeas of Nepal. Small Mammals Conservation and Research Foundation, Kathmandu, Nepal.

Thapa, S., Katuwal, H.B., Gurung, R., Kusi, N., Devkota, B., Shrestha, B., \& Suwal, T.L. (2018). Pikas in Nepal. Small Mammals Conservation and Research Foundation, Kathmandu, Nepal. 